Original Research Article

\title{
Raising the Curtain: The Impact of Drama in Developing the Speaking Skills of ESL learners in Mongolia
}

Rommel Maglaya, PhD.

Director of Raffles Centre for English Language Excellence, Raffles International Institute, Ulaanbaatar, Mongolia

Corresponding Author: Rommel Maglaya, E-mail: mr.maglaya@gmail.com

\begin{tabular}{|c|c|}
\hline ARTICLE INFO & ABSTRACT \\
\hline $\begin{array}{l}\text { Article History } \\
\text { Received: July 21, } 2020 \\
\text { Accepted: August 15, } 2020 \\
\text { Volume: } 2 \\
\text { Issue: } 3\end{array}$ & \multirow{3}{*}{$\begin{array}{l}\text { The study utilized drama-infused lessons in English language classes as a tool to } \\
\text { develop the speaking skills of adult ESL learners in Mongolia. The descriptive- } \\
\text { developmental method was utilized in this study, which went through the } \\
\text { process of development, infusion, and try-out of drama-infused language lessons } \\
\text { to develop the speaking skills in English of adult ESL learners. The development of } \\
\text { the participants' speaking skills as they went through the lessons as described. It } \\
\text { was discovered that drama-infused ESL lessons effectively develop the speaking } \\
\text { skills of learners. It made them more confident when it comes to speaking in } \\
\text { front of the class and expressing themselves in English. Hence, the drama-infused } \\
\text { ESL lessons helped develop self-confidence and fostered active participation } \\
\text { inside the ESL classroom. Drama-infused activities also provided an ideal } \\
\text { opportunity for timorous learners to overcome their inhibitions; it sturdily guided } \\
\text { inactive learners to some awareness of others' feelings and led to the more } \\
\text { creative use of the English language in speaking. }\end{array}$} \\
\hline KEYWORDS & \\
\hline $\begin{array}{l}\text { Drama, ESL, language teaching, } \\
\text { speaking skills, education }\end{array}$ & \\
\hline
\end{tabular}

\section{Introduction}

Drama and its complexity encompass multiple angles. From the beginning of time, the drama has been used to celebrate life events, share history, worship gods, and educate people about society. There are hundreds of ways in which drama can be looked at. For Susan Holden (2012) drama means any kind of activity where learners are asked either to depict themselves or to depict someone else in a make-believe situation: "In other words, the drama is concerned with the world of 'let us pretend'; it asks the learner to project himself/herself imaginatively into another situation, outside the classroom, or into the skin and persona of another person" (p.5). The learners may do this on their own or with one or more fellow learners; they may act either in a controlled way under organizational and linguistic guidelines established by the teacher or be left free to work matters out. In both cases, the learners interact with other people and react to what they do and say, making use of their store of language to communicate in a more meaningful manner.

In the academe, numerous language educators have observed the impact of drama activities/performances in bringing their classes to life. Learners' attention is easily captured; even the most lackluster ones perk when class activities involve playacting. They have also enumerated the benefits of infusing drama/theater activities in the class. First, the learners acquire an appreciation of the values brought out in the presentation more effectively than if they were to read, listen, or speak about it. Second, the learners get to grasp people through understanding characters in a play. Third, the learners acquire and develop specific skills related to their role in the play. In short, the drama is indeed a highly creative form of learning.

Drama makes a vital contribution to the development of learners' speaking skills. Until a learner is emotionally and socially secure, he/she will not be able to express him/herself with ease. Also, she stated that good voice and diction are strongly associated with drama. By being immersed in drama-infused activities, learners discover that their voices can be powerful instruments for exactly expressing what they intend to express. In drama presentations or role-playing activities, a learner

Published by Al-Kindi Center for Research and Development. Copyright (c) the author(s). This is an open access article under CC BY license (https://creativecommons.org/licenses/by/4.0/) 
willingly accepts the challenge of speaking, so effective speech practices are developed. Learners become more attentive in refining their language as they begin to see how important it is to have the right words to express what they want to convey.

\section{Rationale}

There are many favorable reasons using drama methods and techniques in the language classroom. Primarily, it provides a great motivation to learn it is entertaining and fun, and. It can also provide varied opportunities for different uses of the English language, and because it engages feelings, it can provide an enjoyable experience of language for learners.

According to Prochazka (2017), "infusing drama in language teaching, means bringing real-life and fantasy situations and characters into the classroom. It necessitates enthusiasm and willingness "to take risks" on both the students and the teacher. In communicative language teaching, drama methods play an important part because of their holistic approach. It is engrained in neuropsychology. The more senses are involved, the more effective and active learning becomes, and the improvements will be lasting".

Aldavero (2008) pointed out that drama activities involve learners at many levels, not only with language and literacy but also in the kinesthetic aspect. There are some areas where drama can be very beneficial in developing learners' communicative competence.

Drama for second language learners can provide an opportunity to develop imagination. The students can go beyond the here and now and even 'walk in the shoes' of another. It provides an opportunity for independent thinking (McCaslin, 2016). Learners are encouraged to express their ideas and contribute to the whole. Drama offers exercises in critical thinking and the chance for the students to be creative.

A good example of this is role-plays in small groups. ESL learners have many situations where they can hone their ideas and cooperation skills when interacting with their classmates. The group task builds social awareness and understanding as they 'walk in the shoes' of another. Drama is an effective method to study human nature and to work with harmony. Role-playing provides the opportunity for a healthy release of emotion in a safe setting, which can relieve the pressure of learning in a second language.

Drama in language teaching enables learners to use what they are learning with practical intent, which is most difficult to explain. Obliging the teacher from the center stage gives learners space to work with language in ways that are enjoyable, memorable, and constantly varying. Therefore, learners can communicate effectively through dramatic means.

Based on the researcher's observations, adult ESL learners are very open in expressing their opinions and ideas during group tasks, especially if the drama method is employed. For this, it is believed that learners must be more immersed in such activities to become more interested in using English as their medium to express themselves. Henceforth, this study aimed to utilize drama in language teaching using drama-infused lessons to improve the speaking skills of adult ESL learners.

\section{Background of the Study}

Mongolia, branded as the land of the blue sky, is a landlocked country situated between Russia to the north and China to the south, deep within the interior of eastern Asia distant from any ocean. The country has a continental climate, with extremely cold winters and short warm summers. Aside from Genghis Khan, the country is also known for its outstanding diversity of scenery made-up largely of highland steppes, semideserts, deserts, and forested high mountain ranges alternate with lakedotted basins.

Before the Mongolian democratic revolution in 1990, the Russian language had been the primary foreign language taught in all educational institutions across the country. The Russian language also functioned as the premier second language in many academic, business, and political situations. Since Mongolia was a satellite nation that was culturally and politically committed to the Soviet empire, the Russian language was of great significance that knowledge of it was often a requirement for higher education and many professional designations (Namsrai, 5). 
The paradigm shift began after the Mongolian democratic revolution in 1990 when post-communist Mongolia received the influence of Western culture, the interest in learning the English language immensely emerged. Thus, the English language study grew vastly in secondary schools, higher education institutions, and private sectors across the country.

Teaching and learning English as a second language (ESL), particularly with adults, meaningfully function in Mongolian education since most jobs require applicants to have at least a conversational level of English.

Since the number of learners has progressively risen in the past years, English became and still, the most learned foreign language in Mongolia, more and more local and international educational institutions have been established to address this growing demand. There are more than forty (40) English language centers operating in Ulaanbaatar, the capital city of Mongolia. One of those centers is Raffles International Institute (RII), the locale of this study, a Singaporean higher education provider, which has been offering adult ESL programs since 2005.

As a chief manager and lecturer in an English language training center in Mongolia, the researcher has first-hand experience handling adult Mongolian ESL learners. For this study, an adult is operationally defined as someone above eighteen (18) years of age. According to the researcher's observations, interviews, and narratives, the participants' biggest challenge is how to develop their speaking skills in English.

The researcher believes that one of the most effective ways to develop the learners' speaking skills is via communicative language teaching, specifically using drama-infused ESL lessons, considering the speaking problems of adult ESL learners and the required English skill at work to achieve. Since so far, drama approaches have not been integrated into any teachertraining in Mongolia.

Current research focuses on using drama-infused lessons as an effective vehicle in developing the speaking skills of ESL learners. Some studies have already shown positive outcomes of drama on the development of oral communication skills of ESL learners (Balagtas \& Beehner, 1990; Aldavero, 2008). According to Garcia (2014), the development of oral communication skills is one of the learners' most impressive accomplishments during the first ten years of life.

Then again, drama-infused activities are mostly used but receive less recognition. However, a limited number of research studies have investigated drama and its possible influence on the development of the speaking skills of adult ESL learners. This research was made to examine the use of drama-infused lessons to develop ESL learners' speaking skills to provide empirical evidence on the impact of drama-infused lessons in the development of speaking skills of ESL learners.

As a language teacher and theater specialist, the researcher believes that there is a strong need to support the learners to develop their speaking skills by teaching the English language through drama-infused lessons. Therefore, the researcher believes that drama is an effective tool for developing speaking skills in English, which happens to be one of the primary objectives of every English as a Second Language class.

\section{Conceptual Framework}

The conceptual framework of this research (Figure 1) is anchored on Savignon's Communicative Language Teaching approach (2008). It is a learner-centered approach to language learning. The teacher serves as a mentor or guide in learning. Varied activities/materials utilized in the teaching-learning process are based on real-life situations. It is closely connected with Alan Maley's (2005) approach to drama in language teaching. He believes that when it comes to personal experimentation in active speaking and using the language, drama provides an exceptional workroom. Through it, the learners can be different people in various situations. In that way, they can begin to get a natural sense of appropriate use of the language.

After carefully considering the conceptual foundations of the study, the Common European Framework of Reference for Languages (CEFR) was consulted. It is an international standard used to describe one's language ability. It describes language ability on a six-point scale ranging from A1 for beginners to C2 for those who have mastered a language. It makes it more convenient for anyone involved in language teaching and testing, such as educators or learners, to see the level of various qualifications. It is also used by employers and educational institutions to equate qualifications to other exams in their country. The teacher-researcher also considered his observations on adult ESL learners' general weaknesses before the development of drama-infused language lessons. 
In the framework, it is shown that drama-infused lessons would be applied to develop the speaking skills of the participants of the study. The lessons that would have been developed would be integrated into selected appropriate English language topics to develop the speaking competencies in English of the participants. These lessons would be evaluated, revised, and edited if found to be wanting per the experts' suggestions. The lessons would then be tried-out for use by the learnerparticipants and then finalized. Finally, the desired result would be the developed speaking skills in English of adult ESL learners. Additionally, these may be used for similar activities of other language educators. The concepts found to provide a robust foundation for the study are the following:

\section{Communicative Language Teaching (CLT) / Learning Approach}

Sandra Savignon popularized the Communicative Language Teaching (CLT) / Learning Approach (2008). Communication is the process of sharing ideas, thoughts, and feelings with other people. These involve the sender, receiver, channel, and feedback. Savignon (2008) posited that "learning how to be better communicators is important to all of us in our private and public lives. Better communication means better understanding of ourselves and others; less isolation from those around us; and more productive, happy lives" (p.4).

Consequently, she highlighted that teaching the language must focus on the language's actual use and not on the structure of the language. Grammar is part of the language and facilitates communication. However, the rules of grammar alone do not make one skillful in using the language. Grammar rules are taught not for memorization or "mechanical" drill exercises but application in oral or written communication.

She also explained the four components of communicative competence. She showed how, through practice and experience in an increasingly wide range of communicative contexts and events, learners gradually expand their communicative competence. It consists of grammatical competence, discourse competence, sociocultural competence, and, finally, strategic competence.

According to Savignon (2008), CLT aids the learners in developing the strategic skills they need for interpretation, expression, and negotiation of meaning; learners can express satisfaction and even amazement.

It gives way to Maley's (2005) approach to drama in language teaching. According to Maley (1983), approaches claiming to develop the communicative, linguistic competence of language learners have flourished. Drama in language teaching is the application in the classroom of the CLT approach. He also pointed out the enormous range and richness of activities which drama offers. In his article, "A Roomful of Human Beings" (1983), he enumerated the reasons why drama techniques must be used. These are:

1. Drama-based activities are designed to encourage fluency.

Opportunities are needed for the relatively uncontrolled use of the language in 'real' or 'realistic contexts, where the language event takes place in real-time, and where the main focus is on the successful conveying of the message, rather than on the correctness of its form.

2. Drama-based activities offer a context of language acquisition, which was rarely the case of the conventional textbook.

Textbooks are the vehicles of learning rather than a stimulus to acquisition. The acquisition seems to occur best when language learners focus on the message, and not on the form. This kind of situation can be provided through drama techniques.

3. Drama-based activities offer many techniques to bi-sociation.

The rich array of diverse stimuli offered by drama activities is the perfect environment for throwing up unusual chance combinations. Furthermore, it may explain the spontaneous popping-up of language during such activities.

4. Drama-based activities stimulate the authenticity of output from students.

The speaker has to have something he wants to communicate, and this has to be appropriate and relevant to the circumstances in which he finds himself.

5. Drama-based activities offer the learner an opportunity to experience for himself the full range of language use. In any one day, a single person may play out many different roles. In any role portrayed, the learner employs different kinds of language. 
6. Drama-based activities foster a whole complex of qualities derived from working cooperatively in groups. When working with others, learners develop a sense of their worth and of that of others. become aware of their strengths and failings and the often-unsuspected qualities of others in the group.

7. Drama-based activities are highly motivating. Included here are problem-solving, project work, and dilemma discussions that give rise to a high degree of motivation.

Language difficulties are largely forgotten in the involvement with the activity in hand, and it is not unusual for students to express themselves using the foreign language.

- Sandra J. Savignon (Communicative Language Teaching /Learning Approach)

- Alan Maley (Drama in Language Teaching Approach)

- Common European Framework of Reference for Languages

- Classroom Observations

1 Conceptualization and preparation of drama-infused activities to be used in ESL lessons.

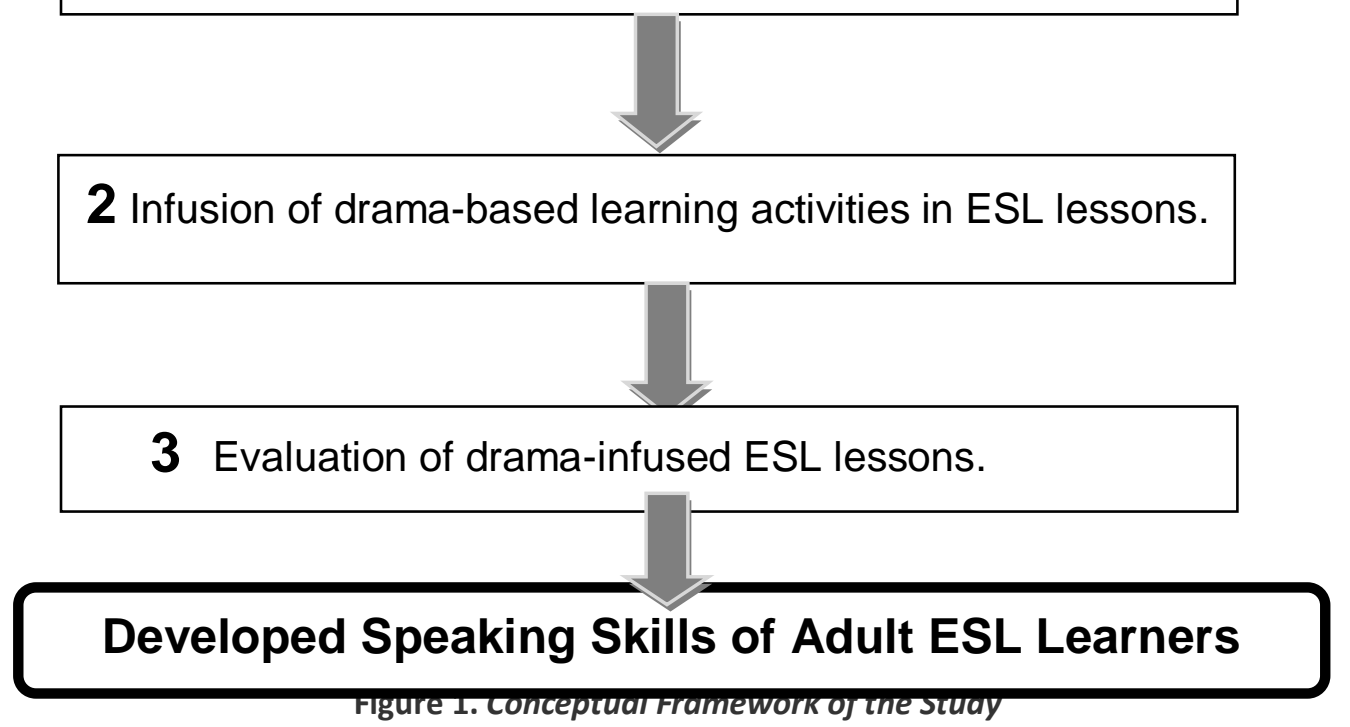

\section{On Oral Communication}

"Language is the door to living and learning" (Salcedo, 2012, p.10). It becomes essential to every human being of any age, race, and color. Moreover, for humans, nothing quite beats language for effective, precise communication. It is by language that people communicate with others expressively. Language is used as a medium of communication. When one person talks, another listens; hence, information is transmitted. Communication could be transmitted in many ways, but the oral language is the source of communication

for most children.

Oral communication skill is critical to children's language fluency. It is the foundation of learning to express and be understood (Farris, 2017). Oral communication skills serve as the "prior skills" in language fluency. By the time children enter their first school, the only way to learning instruction is through listening and speaking. Such listening and speaking serve as media in developing other skills. In the first few years of school, most new information is presented and learned through speaking and listening. Students learn by listening, and they demonstrate what they have learned by talking (Wood, 2015).

Littel (2012) cited that learners who do not develop strong speaking skills find it difficult to keep pace with their peers later. They start to fall behind even before they start school. Oral communication becomes essential to learners as it builds strong support for future language achievement and school success. 
At the most basic level, oral communication means speaking with other people. It uses both listening and verbal language to transact information. Listening and speaking are innate to humans; they are natural abilities that need to be crafted. They are vital to literacy skills. Children learn further through listening and speaking, according to Berk (as cited in Ommaney 1960). Meaningful learning requires effective communication. For effective communication, oral communication skills must be developed because they are the foundation of both communication and learning.

\section{On Language Teaching}

According to Hammerly (2015), language teaching should not be regarded as an intellectual exercise that involves the comprehension and memorization of rule statements, the reading of literature and the memorization of sentences are mechanical conditioning. He stresses that second language teaching/learning involves several of the things enumerated above and many others. It is not anyone exclusively. "The time has come," he points out, "to accept that. For best results, language teaching should not be based on partial theories but comprehensive theories." (p.25).

Wang (2015) designed a strategy focused on speaking which seeks gains in language competency on the following tasks: language habits cultivation through exposure to a wholly English presentation class; creation of a lively atmosphere for communicative activities; presentation of new material in a communicative context rather than isolated sample sentences and provision of a wider range of communication, through language between two or more people.

Brown (2015) extensively sheds much wisdom about current issues in teaching oral communication, including some perspectives in teaching such as pronunciation, accuracy and fluency, affective factors, and the interaction effect. He

1. Cover the spectrum of learner needs, from a language-based focus on accuracy to message-based focus on interaction, meaning, and fluency. In the current teachers' zeal for interactive language teaching, they can easily step into a pattern of providing zesty content-based interactive activities that disregard grammatical pointers or pronunciation tips.

2. Motivate intrinsically. Speaking activities must appeal to the learners' ultimate goals and interests, their need for knowledge, for achieving competence, autonomy, and for "being all they can be." The learners should be helped to see how the activity will benefit them.

3. Encourage the use of authentic language in meaningful contexts.

4. Provide appropriate feedback and correction.

5. Capitalize on the natural link between speaking and listening.

6. Give learners opportunities to initiate oral communication.

7. Encourage the development of speaking strategies.

8. Provide the learners with practice strategies on the following:

a. asking for clarification (what)

b. asking someone to repeat something (huh? Excuse me?)

c. using fillers (uh, I mean, well) in order to gain time to process

d. using conversation maintenance cues (uh-huh, right, yeah, okay, hm)

e. getting someone's attention (hey, say, so)

f. using paraphrase for structure one cannot produce

g. appealing for assistance from the speaker (to get a word or phrase, for example)

h. using formulaic expressions (at the survival stage)

i. using mime and nonverbal expressions to convey meaning.

\section{On Communicative Language Teaching}

Wood (2015) stated that language teachers must be concerned with developing communicative competence, which has been referred to as "one's ability to use and interpret language appropriately in interaction and relation to social context. A corollary investigation provides results on how language is produced, perceived, comprehended, and remembered, used, and acquired (Murcia-Celce, 2014). Also, Prochazka (2017), confirmed that effective language use requires both "organizational knowledge" (what is said) and "pragmatic knowledge" (how it is said). The multi-faceted skills required for the effective use of language merely boils down to the term communicative competence.

Nunan (2013) emphasized the importance of effective language teaching via Communicative Language Teaching (CLT), he stated that CLT makes use of real-life situations that necessitate communication. The teacher sets up a situation that learners are likely to encounter in real life. Unlike the audio-lingual method of language teaching, which relies on repetition and drills, 
the communicative approach can leave students in suspense about the outcome of a class exercise, which will vary according to their reactions and responses. The real-life simulations change from day today. Learners' motivation to learn comes from their desire to communicate in meaningful ways about important topics.

Berns (2015), elucidated that "language is interaction; it is interpersonal activity and has a clear relationship with society"(p.2). In this light, language study has to look at the use (function) of language in context, both its linguistic context (what is uttered before and after a given piece of discourse) and its social, or situational, context (who is speaking, what their social roles are, why they have come together to speak).

\section{On Drama in Language Teaching}

Morrow (2013) affirmed that communicative activities are an effective technique to achieve one of the aims of the communicative approach, which is to obtain communicative competence. The essence of this approach is to communicate with another person in the classroom and, in the long term, society. Drama use in the classroom is considered a communicative activity since it fosters communication between learners and provides opportunities to use the target language in various 'make-believe' situations.

It can be added that drama guides learners understand emotions, solve problems, and better relate to other people. Through their experiences with drama, learners develop their imagination and confidence. One of the most special things about it is that there are no "wrong" answers--through pretending, animals can talk, anyone can travel to outer space or the jungle, and the sky can be green while the grass is blue.

Through drama, learners explore their imagination, learn how to communicate ideas, and learn how to feel comfortable with themselves and their role in society. Davies (1990) asserted that drama strengthens the bond between thought and expression in language, provides practice of supra-segmental and paralanguage and offers good listening practice. If drama is considered a teaching method in the sense of being part of the eclectic approach to language teaching, it can become a main aid in the acquisition of communicative competence. Drama reassures adaptability, fluency, and communicative competence. It puts language into context, and by giving learners the experience of success in real-life situations, it should arm them with confidence in tackling the world outside the classroom.

Hutton (2015) stated that when a learner participates in a drama performance with others, he/she can use language to control his/her surroundings, describe the things that he/she experiences with his/her senses, and organize his/her thoughts. The development of language also allows a learner to describe the string of events in a story and re-enact it.

For Morrow (2013), important skills such as speaking skills and etiquette, learning manners, and overall academic success are all considered positive results of drama-infused activities. The drama takes the learners into a fantasy world -- a world where anything can happen to anyone. It allows the learner to create images in his or her imagination. A learner can vividly transport himself or herself inside the story, become the character, or at least picture the characters and the scenes the way they want to (McCaslin, 2016).

Willson (1994) observed that "drama allows having daily language practice in the safe and relaxed environment of a classroom. This daily language practice will allow the learners to interact on a personal level with both the teacher and classmates." He highlighted that the learners could gain language knowledge from their participation both as speakers and listeners. These personal interactions are meaningful because the learners can interact with one another, carry on conversations, and hear significant rules being modeled involving sentence structure. The skills learned in drama performances develop the learners' speaking skills necessary for them to become successful academic learners in the classroom.

\section{Method}

The descriptive-developmental method was utilized in this study, which went through the process of development, infusion, and try-out of drama-infused language lessons to develop the speaking skills in English of adult ESL learners. The development of the participants' speaking skills as they went through the lessons as described. 
The Phases of the Study

The study followed a four-phase process, as shown in Figure 2.

Phase 1- This centered on the conceptualization and preparation of suitable drama-infused language lessons. The preparation involved the following:

- Identification of the competencies

This phase involved identifying the competencies needed to be developed for effective speaking; Cambridge Interchange Speaking Rubric (2017) was consulted to develop a checklist of speaking skills of adult ESL learners. The list of speaking skills was the basis for the construction of an assessment scale for effective speaking skills in English. Class observations were also conducted before the pretest was given to the learner-participants.

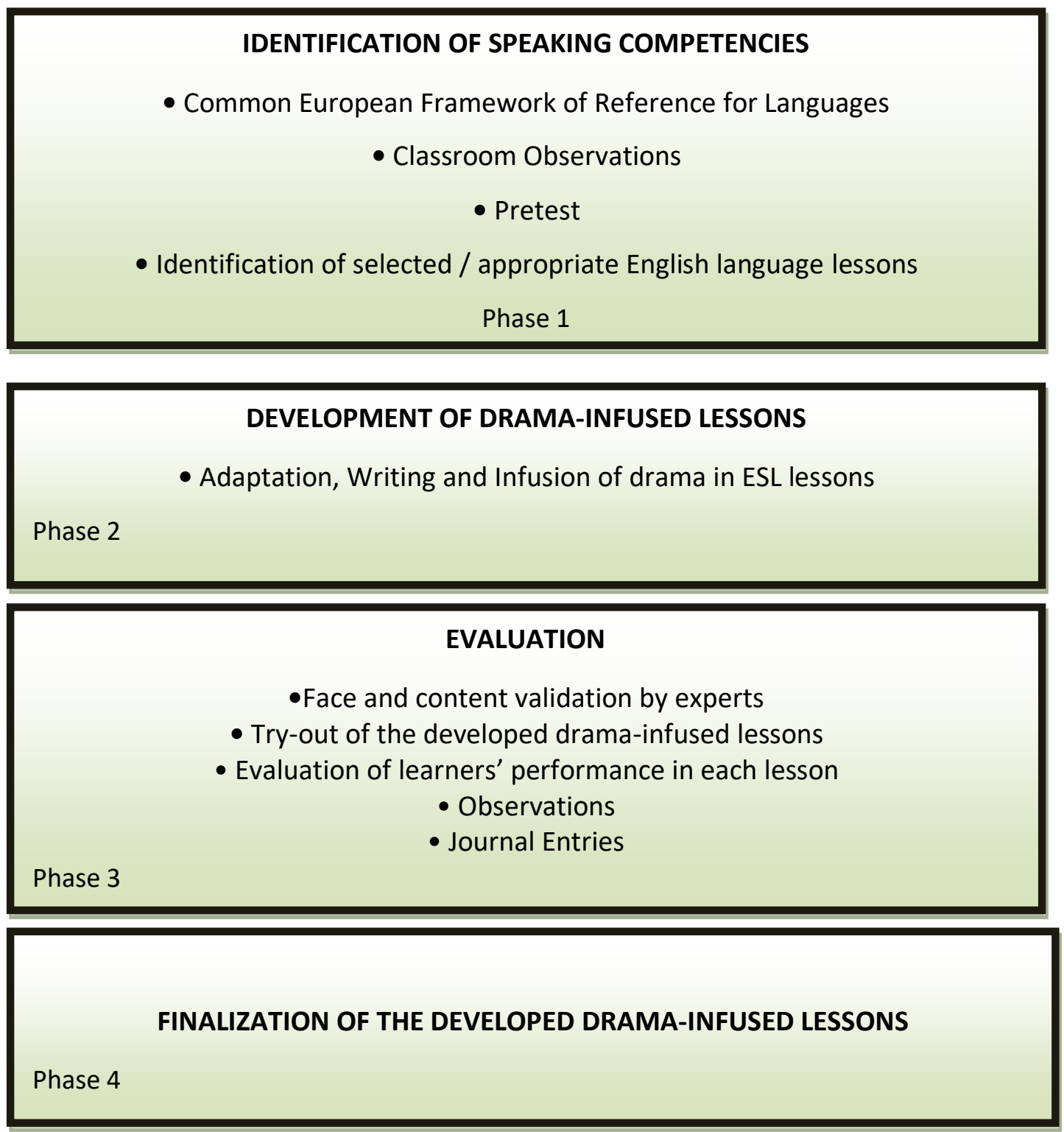

Phase 2

Writing of the Activities

In writing the drama-infused lessons, the researcher followed this format:

- Objective- the statement of purpose for the whole lesson

- Review- a recap of the previous topic discussed

- Presentation- a short explanation of the lesson, and strategy in presenting it

- Practice Exercise- activities are given to the learners to reach mastery of the topic 
- Generalization- learners are guided by the teacher to form concepts derived from the topic

- Speaking Activity- the use of a drama-infused activity to determine mastery of the topic

- Assignment- optionally given to learners, a drama exercise that challenges the learners to maximize their potential on the given topic.

- Teacher Evaluation- contains the rubrics in evaluating the learners' speaking skills for each activity. The rubrics were developed to check whether the lesson objectives were attained during the lesson. All the items in the rubrics were concentrated on the learners' speaking skills in English.

On the actual writing of the lessons, the researcher considered the language to be used, the fluidity of the lesson, and communicative activities appropriate to the learners' needs. Each language lesson was delivered using communicative language teaching designed to develop the speaking skills of adult ESL learners while they experience drama. There were also activities given to encourage learner-participation, and the researcher guaranteed that each activity provided an enjoyable and meaningful experience.

\section{Development / Adaptation of the Activities}

After developing the drama-infused ESL lessons, the researcher reviewed them several times to ensure that each lesson's objectives are attainable. Instructions were made simple, clear, and specific. The activities were checked for grammatical, typographical, and other errors. The suggestions of the research adviser were also considered. These included adding more activities that could help learners communicate with each other, emphasize speaking skills and learner-centered activities, and consult more experts in drama and English language teaching.

Phase 3- This was the evaluation stage. The activities were then subjected to face and content validation by the research adviser. A group of ESL lecturers later validated these. As a teacher of English, the researcher used the developed activities in teaching language lessons to a class of adult intermediate ESL learners. Learners were asked to participate in class discussions, as they normally do, and ask to follow specific instructions to optimize the results of the lessons' conduct- that is, to develop their speaking skills. The learners were observed, interviewed, and asked to write journal entries. The teacherresearcher likewise recorded his observations in a journal. The learners' performance was rated using a rubric designed for each lesson and activity presented.

Phase 4- The developed drama-infused lessons were then finalized.

\section{Data Gathering Tools}

The researcher utilized consultation, observation, and journal entries to gather data. Observations were done daily in class throughout the three-week try-out of the activities.

- The Cambridge Interchange Speaking Rubric (2017) was consulted to identify the appropriate English language lessons for each topic.

- Through observation, the researcher recorded how learners acted and participated in the conduct of the lessons.

- A pretest was conducted to find out what speaking skills needed to be developed.

- Teacher Evaluation of the learners' performance utilized a rubric for each activity. The rubrics were developed to check whether the objectives set were attained during the lesson.

- Journal Entries, written by the learners-participants, provided the researcher to write insights from the respondents about the activities given to them. The researcher was able to know what the learners gained from the given dramainfused lessons. The teacher-researcher himself also had kept a journal where he wrote his observations of the class in every lesson.

- The content validation instrument employed in the study was adapted from (2010), who used it in his study "The Use of Drama to Maximize the Students' Participation in an English Class." Some of the criteria were revised to suit this study.

\section{Participants of the Study}

The participants of the study are the following:

1. The Teacher-Researcher

2. The Expert-Validators were five lecturers/drama experts handling English Language classes in the intermediate level and drama expert. Among the five (5), there was only one male (1) and four (4) females with an average number of sixteen years (16) in the profession. All these validators had either finished or were finishing their graduate studies. 
The teacher-validators were asked to give their suggestions and recommendations for the developed drama-infused activities.

3. The Learner-Participants who were twenty-nine (29) adult intermediate ESL learners consisting of nineteen (9) males and twenty (20) females of Raffles International Institute located in Ulaanbaatar, Mongolia on whom the drama-infused lessons were tried out.

\section{Results and Discussion}

The learner-participants were observed for five (5) days in their respective English language classes. Results show that learners are not comfortable and fluent in using English as the medium for oral communication. The objective of the observations was used to substantiate the competencies needed to be developed for effective speaking skills in English.

After comprehensive analyses of the observations' results and the pretest, the researcher saw the need to design activities that would develop the learners' speaking skills in English. These competencies were chosen based on the Cambridge Interchange Speaking Rubric (2017) inspection, observations, pretest administered to the learner-participants, the teacherresearchers classroom teaching experiences, course syllabi, textbooks, and workbooks used in the subject and other related literature. These are the speaking competencies identified:

$\begin{array}{ll}\text { a. } & \text { Speaks clearly } \\ \text { b. } & \text { Uses correct pronunciation } \\ \text { c. } & \text { Speaks fluently } \\ \text { d. } & \text { Projects / modulates voice appropriately } \\ \text { e. } & \text { Uses voice correctly } \\ f . & \text { Uses face and body expressively in communicating ideas } \\ g . & \text { Shares and contributes ideas }\end{array}$

After the identification of the competencies for effective speaking, the drama-infused ESL lessons were developed. Each lesson was patterned after the lesson plan used in most adult ESL classes at the locale of the study. The drama-infused ESL lessons are not novel; some were gained from theater games, daily teaching, and researcher readings. The researcher designed activities that encouraged participation and used realistic scenarios to provide authentic and spontaneous use of English.

The set of activities was first subjected to face and content validation by the adviser before presentation to the experts for content validation and try-out.

The developed drama-infused lessons were integrated into appropriate language lessons to develop the speaking skills in English of the adult ESL learners. These activities were used in the lesson as a motivational activity, lesson presentation technique, practice exercise, or speaking enhancement activity. In choosing the appropriate activities, the researcher considered the appropriateness and objective of the language lesson.

While doing these activities, the teacher-researcher has observed how drama-infused lessons have helped the adult ESL learners develop their speaking skills. The teacher-researcher asked the participants to write their thoughts about the activities given to them. Here are some of the insights:

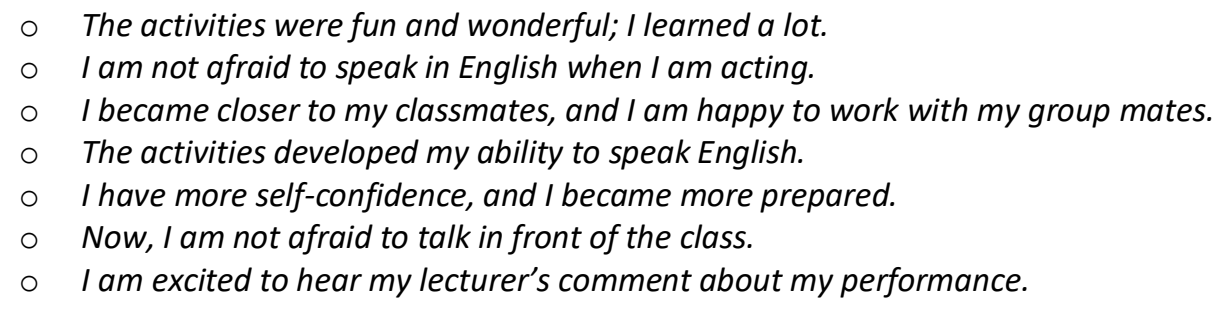

\section{Summary of Findings}

The study came up with the following findings:

1. Seven competencies were identified to need enhancement for effective speaking skills in English of adult ESL learners.

These were: 

a. speaks clearly
b. uses correct pronunciation
c. speaks fluently
d. projects / modulates voice appropriately
e. uses voice correctly
f. uses face and body expressively in communicating ideas
g. shares and contributes ideas

2. The experts found the drama-infused lessons are excellent in terms of their objectives, motivational techniques, appropriateness to lessons, realistic scenarios, procedural instruction, method of assessment, and language use.

2.1 There was a gradual development in English learners' speaking skills as the activities progressed based on the researcher's evaluation of learners' performance in every lesson.

3. Learners became more comfortable speaking in front of the class and expressing themselves using English as a medium for oral communication. They have also shown enthusiasm in performing group tasks, which required them to use speaking skills.

\section{Conclusion}

Based on the findings of the study, these conclusions were drawn:

a) The drama-infused language lessons can be used to develop speaking skills; b) the gradual development in learners' speaking skills in English as the lessons progressed indicate that using drama-infused lessons is effective in developing the speaking skills in English of adult ESL learners; c) learners became more comfortable in speaking in front of the class and in expressing themselves using English as a medium for oral communication. Hence, the activities helped promote the building of self-confidence; d) the classes were lively; therefore creative drama-based activities are helpful tools in arousing learners' attention and interests; e) drama-infused lessons provide an ideal opportunity to help timid learners overcome their inhibitions; it sturdily guided inactive learners to some awareness of the feelings of others and led to the more creative use of the English language in speaking.

Everything considered drama in the English language classroom is ultimately indispensable because it gives learners the chance to express their personalities. It draws upon learners' natural abilities to imitate and express themselves, and if well-handled, should arouse interest and imagination. Drama encourages adaptability, fluency, and communicative competence. It puts language in context, and by giving ESL learners experience of success in real-life situations, it could arm them with confidence to face the world outside the classroom.

\section{Recommendations}

The following recommendations are given:

1. language teachers can use, create or adapt drama-infused lessons as a teaching strategy to help learners develop their speaking skills;

2. in-service / higher education institutions should provide courses on the use of drama techniques in ESL teaching.

3. ESL learners must have more exposure to drama-infused lessons to make learning enjoyable and meaningful

4. educators can explore the possibilities of using drama as a teaching strategy to arouse learners' interest and encourage active participation

5. school/training centers administrators must integrate drama in the curriculum to develop speaking skills of ESL learners.

6. Future language and communication teacher-researchers can conduct further study in drama in language teaching and other communication skills.

There are many reasons in favor of using drama activities and techniques in the language classroom. They are entertaining and fun and can motivate them to learn. They can offer varied opportunities for different uses of language, and because they engage feelings, they can provide a rich experience of language to the participants. 


\section{References}

[1] Aldavero, V. A. (2008). Drama in the development of oral spontaneous communication. British Council - MEC bilingual project.

[2] Balagtas, A. (1990) Creative dramatics: A tool to effective instruction in communication arts for intermediate pupils, unpublished thesis, Manuel S. Enverga University.

[3] Beehner, M.B. (1990). Creating a dramatic script for dynamic classroom learning. "Education", 110(3) 283-288.

[4] Berns, M. S. (2015). Functional approaches to language and language teaching: Another look. PA: Addison-Wesley.

[5] Brown, H. D. (2015). Teaching by Principles: An interactive approach to language. 4th edition. Englewood Cliffs, NJ: Prentice Hall Regents.

[6] Castano, P., Constantino-Salazar, L., \& Pascua, M. (1987). Moving on through language. Quezon City: Abiva Publishing House, Inc.

[7] Davies, P. (1990). The use of drama in English language teaching. TESL Canada Journal. 87-99.

[8] Farris, P. J. (2017). Language arts: Process, product and assessment. lowa: Benchmark Publishers.

[9] Flordeliza, R. (1996) The theater arts: A springboard for total art appreciation, unpublished thesis, Philippine Normal University.

[10] Gabrentina, A. (2006) Proposed activities for enhancing oral communication skills of first year high school students, unpublished seminar paper, Philippine Normal University.

[11] Garcia, B. (2014) Roles of creative drama in early childhood education, [Unpublished undergraduate thesis] Philippine Normal University.

[12] Gimpao, N. (2005) Enhancing oral communication skills through drama-based activities, unpublished thesis, Philippine Normal University.

[13] Goldberg, M. (1974). Children's theatre: A philosophy and method. New Jersey: Prentice Hall.

[14] Gonong, G. (2013) Development and try-out of a prototype drama production-based module for improving the communication skills in English, unpublished thesis, Philippine Normal University.

[15] Hammerly, H. (2015). An integrated theory of language teaching and its practical consequences. Washington: Second Language Publications.

[16] Hodgson, J. \& Banham, M. (1975). Drama in education: The annual survey. London: Pitman Publishing.

[17] Holden, S. (2012). Drama in language teaching. England: Longman Group Ltd.

[18] Hubbard, Peter, et al. (1986) A Training Course for TEFL. Oxford University Press.

[19] Hutton, Melee J. (1982). Dynamic Dialogues. Canada: Friesen Press.

[20] Littell, J. (2012). Building English skills. California: The Macmillan Company.

[21] Maley, A. (1983). A Roomful of Human Beings. RELC Journal, pp. 1-8.

[22] Maley, A. \& Duff, A. (2005). Drama techniques in language learning. New York: Cambridge University Press.

[23] McCaslin, N. (2016). Creative drama in the classroom and beyond. Boston: Pearson Education, Inc.

[24] Morrow, K. (2013): Principles of communicative methodology. New York: Longman.

[25] Murcia-Celce, M. (2014). Teaching English as a second or foreign language. $4^{\text {th }}$ edition. USA: National Geographic Learning.

[26] Nabong, R. (2007) Integrating creative drama in the teaching of oral communication in English, unpublished thesis, Naga College Foundation.

[27] Namsrai, Mira (2004). Language planning policy in Mongolia. Diss. University of HumanitiesUlaanbaatar, Mongolia.

[28] Namsrai, Mira (2004). English language curriculum standards. Ulaanbaatar: Mongolian Ministry of Education Culture and Science.

[29] Napallatan, J.D.P. (2010) The use of drama to maximize the students' participation in an English class, unpublished special project, Philippine Normal University.

[30] Nunan, D. (2013). Learner-centered English language education. NY: Routledge.

[31] Pangilinan, E. \& Dilig, M. (2016). Speech and drama. Manila: National Bookstore Publishing.

[32] Prochazka, A. (2007). Drama in modern language teaching. Federal Pedagogical Institute of Vienna.

[33] Richards, J. (1985). Conversational competence through role-play. RELC Journal 16:1, pp. 82-100.

[34] Richards, J. (2017). Cambridge interchange. $5^{\text {th }}$ edition. New York: Cambridge University Press.

[35] Rupisan, M. E. (2009) Communicative-based activities in teaching speech communication, unpublished thesis, Mariano Marcos State University.

[36] Salcedo, E.M. (2002). Communicative learner-centered instruction: A Guide to teaching-learning ESL/EFL and literature through activities. Gen. Santos City: Wilmond Press.

[37] Savignon, S. J. (2008). Interpreting communicative language teaching: Contexts and concerns in teacher education. USA: Yale University Press.

[38] Tungpalan, L. B. (2000) Development and validation of creative drama-based modules inteaching speech and drama in the Tertiary Level, unpublished Thesis, Philippine NormalUniversity.

[39] Wang, Y. (2016). Drama in language teaching as a second language- A communicative approach.

[40] Wilson, G. D. (1994). Psychology for performing artists: Butterflies and bouquets. New York: Brunner-Routledge-Taylor \& Francis.

[41] Wood, D. (2015). Formulaic language and communicative language teaching. London/New York: Continuum. 